Creative Commons User License: CC BY-NC-ND

Abstracted by: EBSCOhost, Electronic Journals Service (EJS),

Google Scholar, Journal Seek, Scientific Commons,

Food and Agricultural Organization (FAO), CABI and Scopus
Journal of Agricultural Extension

Vol. 23 (4) October, 2019

ISSN(e): 24086851; ISSN(Print); 1119944X

http://journal.aesonnigeria.org

http://www.ajol.info/index.php/iae

Email: editorinchief@aesonnigeria.org

\title{
Male and Female Participation in the Implementation of Fadama III Additional Financing Project among Cassava Farmers in Anambra State, Nigeria https://dx.doi.org/10.4314/jae.v23i4.14
}

\author{
Nwoye, Ifeanyi Innocent \\ Department of Agricultural Economics \& Extension, \\ Chukwuemeka Odumegwu Ojukwu University, Igbariam Campus, Nigeria \\ Email: ifeanyichukwu.nwoye@gmail.com \\ Phone: 08033512812, corresponding author
}

\author{
Nwalieji, Hycienth Udeanya \\ Department of Agricultural Economics and Extension, \\ Chukwuemeka Odumegwu Ojukwu University, Igbariam Campus, Nigeria \\ Email: nwalieji73@yahoo.com \\ Phone: 07033994751
}

\section{Abstract}

The study examined the level of male and female participation in the implementation of Fadama III - Additional Financing project among cassava farmers in Anambra State, Nigeria. Multi-stage sampling technique was used to select 120 cassava farmers that participated in Fadama III - Additional Financing project. Primary data were collected using interview schedule, while paired sample t-test and multiple regression analysis were used to analyse the data. Findings reveals that the male respondents were mainly active in the project activities such as need assessment $(\bar{x}=2.65)$, development of business plan $(\bar{x}=2.65)$ and production group formation $(\bar{x}=2.63)$, while strong linkage to financial institution ( $\bar{x}=2.82)$, conflict resolution $(\bar{x}=2.72)$, monitoring and evaluation $(\bar{x}=2.67)$ and strong linkage to off takers $(\bar{x}=2.60)$ were more actively carried out by the female respondents. Both the male and female respondents benefited immensely from the project in terms of access to improved farm inputs access to facilitator, provision of training, increase in yield, increase in farm size, adequate information on good production practices and low cost of labour. Untimely provision of inputs, irregular advisory services, corrupt practices, lack of access to credit and poor road network were regarded as the major constraints to male and female participation in the project activities. There was significant difference $(t=2.50$, $p \leq 0.05)$ in the level of participation between male and female farmers in the project. However, the females participated more in the project's activities, and the socioeconomic characteristics of the respondents did not influence their levels of participation. Male farmers should be sensitized and encouraged in order to participate actively in the project activities.

Keywords: Cassava farmers, participation by sex, fadama, additional financing

\section{Introduction}

Nigeria is a country endowed with underground and surface water reserves, rich pastures and favourable agro-ecological conditions in its low-lying plains. Some of these low-lying plains that are rich in alluvial deposits are referred to as Fadama (Onugu, Gbughemobi and Okonkwo, 2016). Fadama lands with its residual moisture offer attractive opportunities for the arable farmers to grow both season and off-season high-value crops. The essence of 
Creative Commons User License: CC BY-NC-ND

Abstracted by: EBSCOhost, Electronic Journals Service (EJS), Google Scholar, Journal Seek, Scientific Commons,

Food and Agricultural Organization (FAO), CABI and Scopus
Journal of Agricultural Extension

Vol. 23 (4) October, 2019

ISSN(e): 24086851; ISSN(Print); 1119944X

http://journal.aesonnigeria.org

http://www.ajol.info/index.php/iae

Email: editorinchief@aesonnigeria.org

growing crops like vegetables, cereals and others in the Fadama flood plain land is principal to utilise the residual moisture during the dry season (Daudu, Matanmi, Komolafe and Ajibola, 2015). It is worthy of note that the desire to harness the verse potentials of Fadama in Nigeria culminated in the design of National Fadama Development Projects I, II, III and then Fadama III - Additional Financing.

Fadama III Additional Financing, which is an extension of Fadama III, aims at sustaining an increase in the income of users of rural land and water resources (Agunloye, Fasina, and Akinnagbe, 2017). The project is to scale up the impacts and the development effectiveness of a well-performing project by aligning it more closely with the new Agricultural Transformation Agenda, which was adopted by the Government of Nigeria in 2011. The project has been consistent with the development objective of the parent project and as such, no major changes were made to the Project Development Objective, design or implementation arrangements of the original project. Nevertheless, the main difference is that instead of national coverage as in the case under the parent project. The AF has a narrow geographical focus on clusters of farmers in selected states with comparative advantage and high potential to increase production and productivity of cassava, rice, sorghum and horticulture value chains and link them to better-organised markets (National Fadama Coordination Office (NFCO, 2018; Dayo, Olumuyiwa, Yarama, Malomo and Ekong, 2018)

In a bid to curb the issue of gender inequality, poverty and hunger, successive Nigerian governments have initiated and implemented series of agricultural development projects and programmes with very few making significant impact. While most of them had little or no effect on the lives of the people and this has made manifest in the level of food unavailability, hunger, crises and poverty level in the country. Such programmes and projects included and not limited to the River Basin Development Authorities; National Accelerated Food Production Project; Agricultural Development Project; Operation Feed the Nation; the Green Revolution; National Directorate of Food, Roads and Rural Infrastructure; Agricultural Credit Guarantee Scheme Fund and National Special Programme for Food Security. These programmes were aimed at increasing local food production, increasing income of farmers, improving the living condition of the poor, women and other vulnerable groups among other good intentions of the government in order to ultimately reduce poverty, which is one of the Millennium Development Goals (MDGs). Fadama III - Additional Financing being one of those numerous agricultural development projects implemented in Nigeria was introduced to reduce poverty by improving the living condition of both male and female farmers living in the rural areas; contribute to food security and increase access to rural infrastructure through the active participation of both genders in the project (NFCO, 2018).

However, one may seek to know the level of male and female participation in the project, bearing in mind that the extent of achievement in any agricultural development programme or project depends largely on the level of participation desired and attained by the participants (Umeh, Chukwu and Oselebe, 2014). More so, most researchers that assessed Fadama I, II and III projects in the study area had concentrated on the economic benefits through increased production output and decreased production cost while other factors such as level of male and female participation have been neglected. For instance, in the study area, studies by Nwachukwu, Okafor, Okafor and Taiwo (2016); Ugwumba and Okechukwu (2014) concentrated on economic benefits whereas there is death information on level of gender participation. This might be one of the reasons behind underperformance in agricultural 
Creative Commons User License: CC BY-NC-ND

Abstracted by: EBSCOhost, Electronic Journals Service (EJS),

Google Scholar, Journal Seek, Scientific Commons,

Food and Agricultural Organization (FAO), CABI and Scopus
Journal of Agricultural Extension

Vol. 23 (4) October, 2019

ISSN(e): 24086851; ISSN(Print); 1119944X

http://journal.aesonnigeria.org

http://www.ajol.info/index.php/iae

Email: editorinchief@aesonnigeria.org

development projects and programmes. Based on this premise, there is need to investigate and compare gender (male and female) participation in the implementation of Fadama III Additional Financing project among cassava farmers in Anambra State, Nigeria. Hence, the study leads to the following research questions;

i. what is the level of male and female farmers' participation in the project?

ii. Are there benefits of the project to various genders?

iii. What are the constraints to gender participation in Fadama III - AF?

\section{Objectives of the Study}

The broad objective of the study was to compare male and female participation in the implementation of Fadama III - Additional Financing among cassava farmers in Anambra State, Nigeria. The specific objectives of the study were to:

i. determine the level of male and female farmers' participation in the various activities of the project;

ii. ascertain the benefits of the project to various gender; and

iii. identify constraints to gender participation among cassava farmers in the project.

\section{Hypotheses}

$\mathrm{Hol}$ : There is no significant difference between the level of male and female participation in the project

$\mathrm{H}_{02}$ : Beneficiaries' socio-economic characteristics have no influence on their level of participation in the project

\section{Methodology}

The study was carried out in Anambra State. Anambra State is located between longitude $6^{\circ} 36^{\prime} \mathrm{E}$ and $7^{\circ} 21^{\prime} \mathrm{E}$ and latitude $5^{\circ} 38^{\prime} \mathrm{N}$ and 6 $6^{\circ} 47^{\prime} \mathrm{N}$. The State comprises twenty-one (21) Local Government Areas, one hundred and seventy-seven (177) autonomous communities that cut across the four agricultural zones namely Awka, Anambra, Aguata, and Onitsha. It has a projected population of $5,527,800$, with the male population of $50.9 \%$ and female 49.1\% (National Population Commission, 2016). The state is bounded in the North by Kogi State, in the West by Delta State, in the South by Imo State, and in the East by Enugu State. It occupies an area of about $4,416 \mathrm{~km}^{2}, 70 \%$ of which is arable land.

The population for the study comprised all the male and female cassava farmers who are members of Fadama III - Additional Financing User Groups in Anambra State. Multi-stage sampling procedure involving purposive and random sampling techniques were used to select one hundred and twenty respondents for the study. In the first stage, there was a purposive selection of four (4) local government areas (that had more production clusters and production groups) out of the eight (8) local government areas that were benefiting from the project. The selected local governments included Awka North, Anambra East, Ogbaru and Orumba South. Second stage involved a random selection of two (2) production clusters (PCs) from each of the four selected local government areas in the State, which gave a total number of eight (8) Production Clusters. Stage III involved random selection of three (3) production groups (PGs) from each of the selected production clusters to arrive at twenty-four (24) PGs selected. Stage IV involved random selection of six (6) cassava farmers (3 males; 3 females) from eighteen (18) Production Groups selected from Awka North, Anambra East and Ogbaru (more cassava farmers were selected from these LGA's because they have more Production Clusters). Whereas, two (2) cassava farmers (1 male; 1 female) were 
Creative Commons User License: CC BY-NC-ND

Abstracted by: EBSCOhost, Electronic Journals Service (EJS),

Google Scholar, Journal Seek, Scientific Commons,

Food and Agricultural Organization (FAO), CABI and Scopus
Journal of Agricultural Extension

Vol. 23 (4) October, 2019

ISSN(e): 24086851; ISSN(Print); 1119944X

http://journal.aesonnigeria.org

http://www.ajol.info/index.php/iae

Email: editorinchief@aesonnigeria.org

randomly selected from the remaining six (6) Production Groups all from Orumba South, thus bringing the total sample size to one hundred and twenty (120) respondents for the study. The data were collected with the aid of interview schedule. The interview schedule was divided into three (3) sections and each section contained relevant questions on the objectives of the study. The questionnaire was administered to the selected one hundred and twenty (120) cassava farmers with the help of three trained enumerators. The IBM SPSS Statistics software, version 23 was used to analyze the data. Percentage and mean score were used to achieve stated objectives of the study. Hypotheses 1 and 2 were tested using paired t-test and multiple linear regression analysis respectively.

\section{Measurement of Variables \\ Level of participation in various activities of the project}

The farmers were asked to indicate their level of participation in Fadama III -AF project on a three (3) point Likert-type scale and their responses were categorized as follows; to a great extent $=3$, to an extent $=2$, and to no extent $=1$. The mean cut-off was 2.0 (derived by dividing the value of 6 by 3 to get the mean cut-off). This implies that any variable with a mean score equal to 2.0 and above was regarded as a high level of participation while any variable with mean less than 2.0 was regarded as a low level of participation in Fadama III AF project.

\section{Benefits of the project}

To determine the benefits of the project in the study area, the farmers were asked to indicate the various benefits derived from Fadama III - AF. Such benefits include training, conflict resolution, increase in farm size cultivated, advisory services, increase in productivity, increase in farm income, access to improved cassava stems, access to credit facilities, increase in yield, adequate storage facilities, access to good road, access to market, regular extension contact, low labour cost, easy access to farm inputs etc.

\section{Constraints to participation in the project}

To identify the major constraints in implementing the project, the cassava farmers were asked to indicate on a 3-point Likert-type scale, how serious each of the various shortlisted problems/challenges militates against effective implementation of the project. Their response categories were: very serious $(\mathrm{VS})=3$; serious $(\mathrm{S})=2$; and not serious $(\mathrm{NS})=1$. These values were added to obtain a value of 6 , which was divided by 3 to get a mean score of 2.0. Any mean score $\geq 2.0$ was regarded as a major constraint. Data were further to exploratory factor analysis procedure, using the principal factor model with varimax rotation in grouping the constraint variables into major constraint factors. However, only variables with loadings of 0.40 and above (10\% overlapping variance) were used in naming the factors.

\section{Results and Discussion}

\section{Level of Male and Female Farmers' Participation in Fadama III-AF}

Table 1 shows the level of participation of the respondents on different activities they took part during the project farming activities. The study indicated that the male respondents were only active in the following project activities such as need assessment $(\bar{x}=2.65)$, development of business plan $(\bar{x}=2.65)$, production group formation $(\bar{x}=2.63)$, training $(\bar{x}=2.50)$, advisory 
Creative Commons User License: CC BY-NC-ND

Abstracted by: EBSCOhost, Electronic Journals Service (EJS),

Google Scholar, Journal Seek, Scientific Commons,

Food and Agricultural Organization (FAO), CABI and Scopus
Journal of Agricultural Extension

Vol. 23 (4) October, 2019

ISSN(e): 24086851; ISSN(Print); 1119944X

http://journal.aesonnigeria.org

http://www.ajol.info/index.php/iae

Email: editorinchief@aesonnigeria.org

services $(\bar{x}=2.37)$ and input disbursement exercise $(\bar{x}=2.35)$. Whereas, activities such as strong linkage to financial institution $(\bar{x}=2.82)$, conflict resolution $(\bar{x}=2.72)$, monitoring and evaluation $(\bar{x}=2.67)$, strong linkage to off takers $(\bar{x}=2.60)$, training $(\bar{x}=2.50)$, advisory services $(\bar{x}=2.40)$ and development of business plan $(\bar{x}=2.03)$ were more and actively carried out by the female respondents. The high-level of participation as shown by both sexes may be attributed to the fact that majority of them are educated and eager to play their role towards the sustainability of food security. This corroborates with the findings of Nwachukwu (2013), who opined that male and female farmers contributes to the nation's food security and participate in different food production activities and in making the key decision for many agricultural activities.

Table 1: Level of participation in Fadama III - AF activities

\begin{tabular}{lcccc}
\hline $\begin{array}{l}\text { Fadama III - Additional Financing } \\
\text { Activities }\end{array}$ & \multicolumn{2}{c}{ Male $(\mathbf{n}=60)$} & \multicolumn{2}{c}{ Female $(\mathbf{n}=60)$} \\
& Mean & Rank & Mean & Rank \\
\hline Need assessment & $2.65^{*}$ & $1^{\text {st }}$ & 1.80 & $9^{\text {th }}$ \\
Development business plan & $2.65^{*}$ & $2^{\text {nd }}$ & $2.03^{*}$ & $7^{\text {th }}$ \\
Production group formation & $2.63^{*}$ & $3^{\text {rd }}$ & 1.65 & $10^{\text {th }}$ \\
Training on best agronomic & $2.50^{*}$ & $4^{\text {th }}$ & $2.50^{*}$ & $5^{\text {th }}$ \\
practices & $2.37^{*}$ & $5^{\text {th }}$ & $2.40^{*}$ & $6^{\text {th }}$ \\
Advisory services & $2.35^{*}$ & $6^{\text {th }}$ & 1.98 & $8^{\text {th }}$ \\
Input disbursement exercise & 1.90 & $7^{\text {th }}$ & $2.60^{*}$ & $4^{\text {th }}$ \\
Strong linkage to off takers & 1.85 & $8^{\text {th }}$ & $2.82^{*}$ & $1^{\text {st }}$ \\
Strong linkage to financial institution & 1.63 & $9^{\text {th }}$ & $2.72^{*}$ & $2^{\text {nd }}$ \\
Conflict resolution & 1.58 & $10^{\text {th }}$ & $2.67^{*}$ & $3^{\text {rd }}$ \\
Monitoring and evaluation & & & &
\end{tabular}

Source: Field survey, 2018 . ${ }^{*} \mathrm{M} \geq 2.0=$ High level of participation

\section{Benefits Derived by Male and Female Participation in Fadama III - Project}

Table 2 reveals that large proportion of the sampled male and female respondents benefited immensely from the supports as offered by Fadama III Additional Financing project in Anambra State, Nigeria. The derived benefits by the male and female respondents include access to improved farm inputs $(95.0 \% ; 100 \%)$ followed by the project input disbursement $(96.7 \%$; 98.3\%). Meanwhile, access to facilitator $(91.7 \%$; $93.3 \%)$, provision of training $(88.3 \% ; 85.0 \%)$, increase in yield $(93.3 \% ; 96.7 \%)$, increase in standard of living $(76.6 \%$; $63.3 \%)$, increase in farm size $(70.0 \% ; 88.3 \%)$, adequate information on good production practices $(78.3 \% ; 76.7 \%)$, access to market $(65.0 \%$; $95.0 \%)$. However, low labour cost (76.7\%; $80.0 \%)$, provision of affordable farm inputs $(71.6 \% ; 78.3 \%)$, provision of adequate farm inputs $(80.0 \% ; 86.7 \%)$ and increase in number of meal per day $(51.7 \% ; 66.7 \%)$ were 
Creative Commons User License: CC BY-NC-ND

Abstracted by: EBSCOhost, Electronic Journals Service (EJS),

Google Scholar, Journal Seek, Scientific Commons,

Food and Agricultural Organization (FAO), CABI and Scopus
Journal of Agricultural Extension

Vol. 23 (4) October, 2019

ISSN(e): 24086851; ISSN(Print); 1119944X

http://journal.aesonnigeria.org

http://www.ajol.info/index.php/iae

Email: editorinchief@aesonnigeria.org

equally benefited by the beneficiaries. Table 2 further indicated that provision of follow-up on training was $(60.0 \% ; 48.3 \%)$, easy access to farm inputs $(61.7 \% ; 78.3 \%)$ and timely arrival of farm inputs (73.3\%; 81.7\%).

The immense benefits as indicated in this study tailors with the key objectives of the Fadama III-AF project, which is to reduce poverty by improving the living condition of the rural people and to increase access to rural infrastructure. The result is in line with the findings of Babatunde, Abraham, Jubril and Temitope (2017) who reported that the benefits accrued from the program by the farmers were a knapsack sprayer, training on record keeping, agrochemicals, fertilizer, improved seeds, a watering can, pest and disease management, conflict resolution, and the construction of a well, borehole, cooling shed and market stall. This implies that majority of both men and women farmers' perceived increase in their agricultural productivity. However, Olaolu, Akinnagbe and Agber (2013), in a study titled "impact of national Fadama development project phase (II) on poverty and food security among rice farming beneficiaries in Kogi State, Nigeria" concluded that Fadama phase-one in Anambra state helped in the upliftment of living standard of benefiting farmers when compared to those that have not participated.

Table 2: Benefits derived from Fadama III additional financing project

\begin{tabular}{lcc}
\hline Fadama III -Additional Financing Activities & $\begin{array}{c}\text { Male } \\
\text { Percentage } \\
\%\end{array}$ & $\begin{array}{c}\text { Female } \\
\text { Percentage } \\
\%\end{array}$ \\
\hline Access to improved farm inputs & 95.0 & 100 \\
Fadama project input disbursement & 96.7 & 98.3 \\
Access to facilitator & 91.7 & 93.3 \\
Provision of training & 88.3 & 85.0 \\
Increase in yield & 93.3 & 96.7 \\
Increase in standard of living & 76.6 & 63.3 \\
Increase in farm size & 70.0 & 88.3 \\
Adequate information on good production practices & 78.3 & 76.7 \\
Access to market & 65.0 & 95.0 \\
Low labour cost & 76.7 & 80.0 \\
Provision of affordable farm inputs & 71.6 & 78.3 \\
Provision of adequate farm inputs & 80.0 & 86.7 \\
Increase in the number of meals per day & 51.7 & 66.7 \\
Provision of follow up on training needs & 60.0 & 48.3 \\
Easy access to farm inputs & 61.7 & 78.3 \\
Timely arrival of farm inputs & 73.3 & 81.7 \\
Access to commercial institution & 26.7 & 35.0 \\
Access to credit & 23.3 & 26.7 \\
Adequate credit facilities & 21.6 & 35.0 \\
Access to good road & 26.7 & 33.3 \\
Timely provision of credit facilities & 28.3 & 18.3 \\
Regular advisory services & 31.7 & 41.7 \\
Easy access to credit & 16.7 & 23.3 \\
\hline SOurCe: Field survey 2018. & &
\end{tabular}

Source: Field survey, 2018. 
Creative Commons User License: CC BY-NC-ND

Abstracted by: EBSCOhost, Electronic Journals Service (EJS),

Google Scholar, Journal Seek, Scientific Commons,

Food and Agricultural Organization (FAO), CABI and Scopus
Journal of Agricultural Extension

Vol. 23 (4) October, 2019

ISSN(e): 24086851; ISSN(Print); 1119944X

http://journal.aesonnigeria.org

http://www.ajol.info/index.php/iae

Email: editorinchief@aesonnigeria.org

\section{Constraints to Participation in Fadama III -AF Project}

Table 3 shows the mean distribution of identified constraints that militates against male and female participation in Fadama III - Additional Financing Project in the study area. The decision was based on the mean cut-off of 2.0 for a 3-point Likert-type scale. Using mean score to rank the constraints according to their order of severity as indicated by the respondents, untimely provision of inputs to the male $(\bar{x}=2.85)$ and female $(\bar{x}=2.62)$ respondents was ranked first. However, for the males, the second major constraints was irregular advisory services $(\bar{x}=2.70)$. This was followed by inadequate access to farmland $(\bar{x}=2.52)$, corruption practices among Fadama staff $(\bar{x}=2.50)$, poverty $(\bar{x}=2.33)$, lack of access to credit $(\bar{x}=2.32)$, poor road network $(\bar{x}=2.22)$, lack of improved cassava stem $(\bar{x}=2.17)$ and poor marketing facility $(\bar{x}=2.13)$, insincerity of Fadama staff $(\bar{x}=2.08)$ and literacy $(\bar{x}=2.03)$. On the part of the female participants, the second major constraints were poor road network $(\bar{x}=2.62)$, followed by corruption practices among Fadama staff $(\bar{x}=2.35)$, lack of access to credit $(\bar{x}=2.34)$, inadequate access to farmland $(\bar{x}=2.33)$, incident of pests and diseases $(\bar{x}=2.24)$, irregular advisory services $(\bar{x}=2.23)$, poor marketing facility $(\bar{x}=2.22)$, literacy $(\bar{x}=2.09)$ and lack of improved cassava stem $(\bar{x}=2.00)$.

The project beneficiaries were generally affected by several factors likely to negatively influence the actualization and success of the project in the near future. The findings agree with that of Muhammed, Umar, Abubakar and Abdullahi (2011) as cited in Nwaobiala (2015) that untimely release of funds was the major constraints, since most of the time the funds (grants) were not given to the beneficiaries at the right time due to hijacking of the programmes by top government officials and public office holders. 
Creative Commons User License: CC BY-NC-ND

Abstracted by: EBSCOhost, Electronic Journals Service (EJS),

Google Scholar, Journal Seek, Scientific Commons,

Food and Agricultural Organization (FAO), CABI and Scopus
Journal of Agricultural Extension

Vol. 23 (4) October, 2019

ISSN(e): 24086851; ISSN(Print); 1119944X

http://journal.aesonnigeria.org

http://www.ajol.info/index.php/iae

Email: editorinchief@aesonnigeria.org

Table 3: Constraints to male and female participation

\section{Constraints}

\begin{tabular}{lcccc} 
& Mean & Rank & Mean & Rank \\
\hline Untimely provision of inputs & 2.85 & $1^{\text {st }}$ & 2.62 & $1^{\text {st }}$ \\
Irregular advisory services & 2.70 & $2^{\text {nd }}$ & 2.23 & $7^{\text {th }}$ \\
Inadequate access to farmland & 2.52 & $3^{\text {rd }}$ & 2.33 & $5^{\text {th }}$ \\
Corrupt practices among Fadama staff & 2.50 & $4^{\text {th }}$ & 2.35 & $3^{\text {rd }}$ \\
Poverty & 2.33 & $5^{\text {th }}$ & 1.97 & $11^{\text {th }}$ \\
Lack of access to credit facilities & 2.32 & $6^{\text {th }}$ & 2.34 & $4^{\text {th }}$ \\
Poor road network & 2.22 & $7^{\text {th }}$ & 2.62 & $2^{\text {nd }}$ \\
Lack of improved cassava stem & 2.17 & $8^{\text {th }}$ & 2.00 & $10^{\text {th }}$ \\
Poor marketing facility & 2.13 & $9^{\text {th }}$ & 2.22 & $8^{\text {th }}$ \\
Insincerity of Fadama staff & 2.08 & $10^{\text {th }}$ & 1.95 & $12^{\text {th }}$ \\
Literacy & 2.03 & $11^{\text {th }}$ & 2.09 & $9^{\text {th }}$ \\
Poor communication & 1.98 & $12^{\text {th }}$ & 1.93 & $14^{\text {th }}$ \\
Inadequate provision of agro inputs & 1.97 & $13^{\text {th }}$ & 1.75 & $16^{\text {th }}$ \\
Insufficient technical know-how & 1.93 & $14^{\text {th }}$ & 1.93 & $13^{\text {th }}$ \\
High cost of inputs & 1.92 & $15^{\text {th }}$ & 1.72 & $17^{\text {th }}$ \\
High labour cost & 1.88 & $16^{\text {th }}$ & 1.72 & $19^{\text {th }}$ \\
Incident of pest and diseases & 1.88 & $17^{\text {th }}$ & 2.24 & $6^{\text {th }}$ \\
Lack of access to agro chemical & 1.82 & $18^{\text {th }}$ & 1.58 & $20^{\text {th }}$ \\
Poor attitude to work by fadama staff & 1.77 & $19^{\text {th }}$ & 1.87 & $15^{\text {th }}$ \\
Disbursement of agro inputs & 1.60 & $20^{\text {th }}$ & 1.25 & $22^{\text {nd }}$ \\
Inadequate storage facility & 1.45 & $21^{\text {st }}$ & 1.72 & $18^{\text {th }}$ \\
Inadequate electricity supply & 1.35 & $22^{\text {nd }}$ & 1.52 & $21^{\text {st }}$ \\
\hline
\end{tabular}

Source: Field survey, 2018. Note: $M \geq 2.0$ is a major constraint

\section{Differences in Level of Male and Female Participation in Fadama III - AF Project}

Table 4 indicates that there was a difference $(\mathrm{t}=2.5)$ between the level of male (2.2) and female (2.3) participation in the project. This suggests that there was significant difference between the male and female farmers' participation in the project at $5 \%$ probability level. The implication of this finding is that the female respondents are participating more in the Fadama III - AF project compared to the male counterpart in the study area. This disagrees with the findings of Daudu et al. (2015) and Oladipo, Dauda, Bolarin, Bello, Aliyu and Orire (2016) that male farmers were more involved in agricultural activities including decision making than their female counterpart in Kwara state. 
Creative Commons User License: CC BY-NC-ND

Abstracted by: EBSCOhost, Electronic Journals Service (EJS),

Google Scholar, Journal Seek, Scientific Commons,

Food and Agricultural Organization (FAO), CABI and Scopus

http://eoi.citefactor.org/10.11226/v23i4
Journal of Agricultural Extension

Vol. 23 (4) October, 2019

ISSN(e): 24086851; ISSN(Print); 1119944X

http://journal.aesonnigeria.org

http://www.ajol.info/index.php/iae

Email: editorinchief@aesonnigeria.org

Table 4: Differences in the level of participation of male and female in the project

\begin{tabular}{|c|c|c|c|c|}
\hline Variables & Mean & $\begin{array}{l}\text { Difference between } \\
\text { Means }\end{array}$ & $\begin{array}{l}\text { Std } \\
\text { Deviation }\end{array}$ & $t$ \\
\hline $\begin{array}{l}\text { Female Level of } \\
\text { Participation }\end{array}$ & 2.335 & 0.1100 & 0.2130 & $2.50^{*}$ \\
\hline $\begin{array}{l}\text { Male Level of } \\
\text { Participation } \\
{ }^{*} \mathrm{P} \leq 0.05\end{array}$ & 2.225 & & 0.2267 & \\
\hline
\end{tabular}

Source: Field survey, 2018

\section{Influence of Socio-economic Characteristics of the Respondents on their level of Participation}

The male and female values of $R^{2}$ obtained were 0.031 and 0.056 respectively while -0.099 and -0.051 were the values of male and female $R^{2}$ adjusted. Result of the regression analysis indicated that out of the seven independent variables utilized in the analysis, none of the socioeconomic variables significantly influenced (age, gender, marital status, educational level, household size, farm size and farming experience) the level of male and female participation in Fadama III Additional Financing.

Table 5: Influence of socio-economic characteristics on the level of male and female participation in Fadama II -AF

$\begin{array}{ll}\text { Male } & \text { Female } \\ \text { Standardize } & \begin{array}{c}\text { Standardize } \\ \text { Coefficient }\end{array} \\ \text { Coefficient }\end{array}$

\begin{tabular}{lcccc}
\hline \multicolumn{1}{c}{ Variables } & Beta & $\mathbf{t}$ & Beta & $\mathbf{t}$ \\
\hline Age & 0.020 & 0.087 & 0.109 & 0.436 \\
Gender & -0.095 & -0.686 & 0.086 & 0.587 \\
Marital status & 0.035 & 0.166 & -0.264 & -1.590 \\
Educational level & -0.057 & -0.359 & -0.036 & -0.258 \\
Household size & 0.031 & 0.178 & -0.051 & -0.294 \\
Farm size & -0.113 & -0.737 & -0.006 & -0.041 \\
Farming experience & 0.034 & 0.167 & 0.010 & 0.046
\end{tabular}

Male: Adjusted $R^{2}=-0.121 ;$ Female: Adjusted $R^{2}=-0.048$; Source: Field survey, 2018

\section{Conclusion and Recommendations}

There were positive and significant differences between the male and female level of participation. Socio-economic characteristic did not influence their level of participation in the project. There is need for prompt payment of counterpart fund by the state, federal government and the World Bank as this will ensure timely disbursement of farming resources, thus addressing the issue of untimely disbursement of inputs as identified by the cassava farmers. There is need for the advisory services and input consultants to be 
Creative Commons User License: CC BY-NC-ND

Abstracted by: EBSCOhost, Electronic Journals Service (EJS),

Google Scholar, Journal Seek, Scientific Commons,

Food and Agricultural Organization (FAO), CABI and Scopus
Journal of Agricultural Extension

Vol. 23 (4) October, 2019

ISSN(e): 24086851; ISSN(Print); 1119944X

http://journal.aesonnigeria.org

http://www.ajol.info/index.php/iae

Email: editorinchief@aesonnigeria.org

motivated in the project as this would make them to be committed towards the attainment of the project goals and objectives. In addition, proactive measures such as timely organization and farmers' enlightenment concerning the project objectives and goals prior to farming season is important, as this may increase their level of participation in the project and as well enable them to know more about the project and what they stand to gain from it. More so, it is recommended that the male farmers should be sensitized and encouraged in order to participate actively in the project activities.

\section{References}

Agunloye, T.O., Fasina, O.O \& Akinnagbe, O.M. (2017). Effects of national fadama III programme on the scope and scale of beneficiaries' farming activities in South West, Nigeria. Journal of Agricultural Extension, 21(2), 79 - 90

Babatunde, M. M., Abraham, F., Jubril, O.A. \& Temitope, O.A. (2017). Effects of Fadama III programme on dry-season vegetable growers in Kwara State, Nigeria. Kasetsart Journal of Social Sciences. 38(2), 163-168.

Daudu, A.K., Matanmi, B.M., Oladipo, F.O., Aliyu, A.S., \& Olatinwo, L.K. (2015). Effect of gender on farmers' level of involvement in arable crop production activities in Kwara State, Nigeria. Journal of Production Agriculture and Technology, 11(2), 145 - 148.

Dayo Phillip , Olumuyiwa O Jayeoba, Yarama Ndirpaya, Gabriel Malomo \& Edet Ekong, (2018). Scaling strategies for agricultural innovations in Nigeria. FARA Research Results, 2(1), 21.

Muhammed, H.U., Umar, B.F., Abubakar, B.Z., \& Abdullahi A.S. (2011). Assessment of factors influencing beneficiary participation in Fadama II Project in Niger State, Nigeria. Nigerian Journal of Basic and Applied Science, 19(2), 248 - 252

National Fadama Coordination Office (2018). An overview of Fadama III - Additional Financing. Retrieved from https://fadamaaf.net/AF/pages/overview.php

Nwachukwu, O.F; Okafor, O.P; Okafor, O; \& Taiwo; A.O (2016). Effects of Fadama III user groups participation on farmers' income. A case study of selected crop farmers in Agricultural Zones and Blocks in Anambra State, Nigeria. International Journal of Community and Computer Studies. 4 (1), 1-13.

Nwachukwu, M.F. (2013). Analysis of gender participation in agricultural food crop production activities in Nigeria. Retrieved from http://repository.unn.edu.ng:8080/xmlui/bitstream/ handle/123456789/1648.

Nwaobiala, C.C (2015). Analysis of factors influencing women participation in cassava post harvest technologies in Abia State, Nigeria. Journal of Sustainable Agriculture and the Environment, 16(2), $341-353$

Oladipo, F.O., Dauda, A.K., Bolarin, O., Bello, O.G., Aliyu, A.S., \& Orire, R.O. (2016). Assessment of gender participation in Fadama III project among smallholder crop farmers in Kwara State, Nigeria. Journal of Production Agriculture and Technology (PAT), 12(1), 57-66.

Olaolu, M.O; Akinnagbe, O.M; \& Agber, T. (2013). Impact of national Fadama development project phase (II) on poverty and food security among rice farming beneficiaries in Kogi State, Nigeria. American Journal of Research Communication, 1(10), 280-295. 
Creative Commons User License: CC BY-NC-ND

Abstracted by: EBSCOhost, Electronic Journals Service (EJS),

Google Scholar, Journal Seek, Scientific Commons,

Food and Agricultural Organization (FAO), CABI and Scopus

http://eoi.citefactor.org/10.11226/v23i4
Journal of Agricultural Extension

Vol. 23 (4) October, 2019

ISSN(e): 24086851; ISSN(Print); 1119944X

http://journal.aesonnigeria.org

http://www.ajol.info/index.php/jae

Email: editorinchief@aesonnigeria.org

Onugu, C.U., Gbughemobi, B.O., \& Okonkwo, P.C. (2016). Behavioral changes among Fadama II project farmers and lessons in agriculture development of Enugu State Nigeria. Journal of Crop Science and Technology, 5(2), 222 - 231.

Ugwumba, C.O.A. \& Okechukwu, E.O. (2014). The performance of Fadama III user groups crop farmers at mid-term in Southeast Nigeria. Scholars Journal of Agriculture and Veterinary Sciences, 1(2), 75 - 82

Umeh, G.N; Chukwu, V.A. \& Oselebe, A.A. (2014). Level of participation and benefits of the National Programme for Food Security (NPFS) among women in Ebonyi State, Nigeria. Global Journal of Agricultural Research. 2(4), 19 - 22. 